\title{
Türkiye'de Bir Yönetim Danışmanı: Urwick Orr and Partners ve Türk Hava Yolları'ndaki Danışmanlık Faaliyetleri (1967-1971) ${ }^{1}$
}

Akansel Yalçınkaya²

Türkiye'de Bir Yönetim Danışmanı: Urwick Orr and Partners ve Türk Hava Yolları'ndaki Danışmanlık Faaliyetleri (1967-1971)

Öz

Bu çalışmada, Urwick Orr and Partners'ın Türk Hava Yolları'na yönelik 1967 ile 1971 yılları arasındaki danışmanlık faaliyetleri incelenmektedir. Bu amaçla, Urwick Orr and Partners'ın Türk Hava Yolları'na yönelik danışmanlık faaliyetlerini derinlemesine analiz etmeye imkân veren tarihsel bir anlatı analizi kurulmuştur. Çalışmanın amacına ulaşmak için aralarında arşiv malzemeleri, çok çeşitli metinler ile gazete haberlerinin olduğu çeşitlendirilmiş bir veri seti derlenmiştir. Danışmanlık faaliyetlerinin bağlam, içerik ve kapsamını keşfetmek için çalışmada anlatı analizi kullanılmıştır. Çalışma sonuçları, söz konusu danışmanlık faaliyetlerinin Kamu İktisadi Teşebbüsleri'ne yönelik daha geniş kapsamlı bir rasyonalizasyon projesinin bir parçası olduğunu göstermektedir.

Anahtar Kelimeler: Yönetim danışmanlığı, yönetim bilgisi transferi, Urwick Orr and Partners, Türk Hava Yolları

\author{
A Management Consultant in Turkey: Urwick Orr and \\ Partners and Its Consulting Services to Turkish Airlines \\ (1967-1971)
}

Abstract

This study examines the consulting services of Urwick Orr and Partners to Turkish Airlines from 1967 to 1971 . For this purpose, a historical narrative approach is constructed to allow for in-depth analysis of consulting services of Urwick Orr and Partners to Turkish Airlines. To reach the aim of the study, the data are gathered from multiple sources that include archival materials, various kinds of text and commentary and archival articles of newspapers. Narrative analysis is used in this study to explore the context, content and scope of consulting servies. Research results show that, this consulting service considered as a part of rationalization project of State Economic Entreprises in Turkey.

Keywords: Management consulting, Transfer of management knowledge, Urwick Orr and Partners, Turkish Airlines

\section{Giriş}

Tarihsel olarak kökenleri endüstri devrimine dayandırılan yönetim danışmanlığı ve bu hizmeti veren danışmanların, yönetim kavramının tarihsel gelişimindeki diğerleri işletme okulları ve iş dünyasına yönelik medya olmak üzere en önemli üç aktörden biri olduğu belirtilmektedir (Engwall vd., 2016). Yönetim bilgisinin üretimi ve yayılımına benzer şekilde (Üsdiken, 2014), yönetim danışmanlığı faaliyetlerinin de doğdukları bir merkez ve transfer edildikleri bazı çevreler bulunmaktadır. Bu bağlamda, Türkiye'nin çoğunlukla uygulamaya dönük ve akademik yönetim bilgisini merkez ülkelerden ithal eden bir çevre ülkesi olduğu da zikredilmektedir (Özen, 2014). Bu noktadan hareketle, yönetim ve örgüt araştırmaları yazınında bir çevre ülke olarak Türkiye'ye akademik yönetim bilgisinin (Üsdiken, 1996; Üsdiken ve Çetin, 2001; Üsdiken, 2004) ve bazı yönetim uygulamalarının (Özen ve Berkman, 2007; Erçek ve Say, 2008) transferine ilişkin zengin bir bilgi birikimi yanında; ana odak olarak yönetim danışmanlığını almamakla birlikte bu hususa ilişkin içeriğe sahip birkaç istisna (Özen Aytemur, 2010; Topal vd., 2012) dışında, özellikle

\footnotetext{
${ }^{1}$ Bu çalışma, 9 Nisan 2018 tarihinde İstanbul Üniversitesi İşletme Fakültesi tarafından düzenlenen I. İşletme ve Yönetim Tarihi Konferansı'nda sunulmuş olan özet bildiriden geliştirilerek ve gözden geçirilerek üretilmiştir. Çalışmayı gerçekleştirirken bazı eserlere ulaşmada yardımlarını gördüğüm Kalkınma Bakanlığı Kütüphanesi'nden Can Armutçu'ya, mülakat teklifimi kabul ederek görüşlerini paylaşan Türk Sevk ve İdare Derneği'nin eski mensupları Ergun Zoga, Ege Cansen ve Ali İhsan Poyraz'a ve değerli görüş, öneri ve eleştirileri için çalışmanın anonim iki hakemine ve editöryel katkı ve destekleri için dergi editörlüğüne çok teşekkür ederim.

${ }^{2}$ Arş. Gör. Dr., İstanbul Medeniyet Üniversitesi Turizm Fakültesi Turizm İşletmeciliği Bölümü. akansel.yalcinkaya@medeniyet.edu.tr, Yazar ORCID bilgisi: http://orcid.org/0000-0002-7843-0612
} 
yönetim danışmanları tarafından gerçekleştirilen yönetim bilgisi ithaline yönelik görgül ilginin daha düşük düzeyde kaldığı söylenebilir. Bu husus, hele ki daha erken dönemlere ilişkin Türkiye'deki örgütlere yönelik danışmanlık faaliyetleri ve yönetim danışmanlığı mekanizması aracıIığıyla gerçekleştirilen yönetim bilgisi transferine ilişkin tarihsel sınamalar söz konusu olduğunda daha da belirginleşmektedir.

Bu çalışmada, söz konusu bu ihmal edilmişliği bir nebze olsun gidermek üzere, bir çevre ülke olarak Türkiye'de görece daha erken denilebilecek dönemlerde bir yönetim öncüsü (Brech vd., 2010) olarak anılan Lyndall F. Urwick'in kurucu ortaklarından biri olduğu ve o dönem ülkesindeki önde gelen yönetim danışmanlığı şirketlerinden biri olan (Engwall vd., 2016) Urwick Orr and Partners'ın 1967 ile 1971 yılları arasında Türk Hava Yolları'ndaki danışmanlık faaliyetleri inceleme konusu yapılmıştır. Çalışma, incelemeye temel teşkil eden kuramsal yaklaşımın ele alındığı bir bölüm ile devam edecek olup; hemen ardından incelemenin hangi yazına yaslandığına yönelik izahat verilecektir. Bunun devamında, incelemeye ilişkin yöntemsel tercihlerin detaylandırıldığı bölümün ardından; söz konusu danışmanlık faaliyetlerinin ortaya çıktığı bağlam ile bu süreçte etkili aktörler ele alınacak ve danışmanlık faaliyetlerinin içeriği ile sonuçları değerlendirilerek çalışma sona erecektir.

\section{Kuramsal Çerçeve: Yönetim Bilgisinin Yayılımı}

Her bilimsel disiplinde olduğu gibi, yönetim ve örgüt araştırmaları alanında da kuramların üretilip kendi bağlamları dışına transfer edildiği bir merkez ile söz konusu bu kuramları transfer eden çevreler bulunmaktadır (Özen, 2014). Yönetim ve örgüt çalışmaları bağlamında, merkez ve çevre kavramlarını tanımlamak için öncelikle söz konusu bu kavramları birbirleriyle ilişkili olarak incelemek gerekmektedir. Bu bağlamda, ilginç bir şekilde çevreyi tanımlamak için merkezin varlığına ihtiyaç duyulmaktadır. Buna göre, merkez, ilgili alandaki ana bilgi üretimini yapan ve dünya genelindeki etkinin ana kaynağı şeklinde ele alınırken (Alatas, 2003); yönetim ve örgüt araştırmaları ve özellikle de yönetim bilgisinin yayılımı bağlamında düşünüldüğünde, yazında tek bir merkezin bulunduğu ve bunun da ABD olduğu zikredilmektedir (Kipping vd., 2004; Engwall, 2007). Yönetim ve örgüt araştırmaları alanı, genelde 1970 'lerden sonra koşul bağımlılık kuramına karşı olarak ortaya çıkan ve genellikle Kuzey Amerika kökenli kuramların etkisi ile şekillendiği için; yönetim ve örgüt yazınına egemen anlayışın, daha çok Avrupa ve Amerika kökenli olmak üzere; özellikle 2. Dünya Savaşı sonrasında Amerikan etkisi ve egemenliğinin tüm dünyada daha da ön plana çıktığı söylenebilir (Üsdiken, 1996). Dahası, 20. yüzyıl boyunca, ABD'nin yönetim bilgisinin ana üreticisi ve daha da önemlisi ana dağıtıcısı (diffuser) olduğu dahi vurgulanmaktadır (Guillén, 1994). ABD’nin önder konumunun güçlenmesinde o dönemde Amerikan şirketlerinin başarılarının payı olmuştur. Buna göre, savaş sonrasında Amerikan yardımıyla yeniden kurulan Batı Avrupa'da, Amerikalıların yönetim modellerinin üstünlüğü hiçbir tartışma götürmemiştir (Üsdiken ve Selekler, 1996:263). Bununla birlikte, merkez-çevre ayrımının bağlamsal kesinliğinin yanında merkezden çevreye doğru süregiden bir süreklilik (continuum) arz ettiği; bu bağlamda da ABD gibi merkezler, Büyük Britanya gibi yarı merkez veya ikincil çevreler (Üsdiken, 2007; Üsdiken ve Wasti, 2009) ile birlikte bunların dışında da Türkiye gibi (Özen, 2014) çevre ülkelerin bulunduğu söylenmektedir.

Küresel yönetim bilgisinin coğrafi konumu böyle iken, yönetim bilgisinin üretildiği bağlamlardan diğer bağlamlara doğru yayılımı önem arz etmekte; ve fakat daha endüstrileşmiş ve gelişmiş ülkelere yönetim bilgisinin yayılımına ilişkin var olan literatüre karşın, çevre ülkelere söz konusu bilginin transferine yönelik yazının henüz emekleme döneminde olduğunun altı çizilmektedir (Kipping vd., 2008:12). Yönetim bilgisinin merkezden çevreye transferini incelemek 
için farklı yaklaşımlar arasında transfer sürecinde bilgiyi ihraç ve ithal eden taşıyıcıları öne alan (Djelic, 2001; Sahlin-Andersson ve Engwall, 2002; Djelic ve Sahlin-Andersson, 2006) aktör merkezli yaklaşım olarak adlandırılabilecek bir yaklaşım son yıllarda öne çıkmış ve görgül ilgi kazanmıştır. Aktör merkezli yaklaşım bağlamında, Sahlin-Andersson ve Engwall (2002), yönetim bilgisinin transferi süreci için taşıyıcı kavramını öne sürmüşlerdir. Sahlin-Andersson ve Engwall (2002), yönetim bilgisi transfer sürecini taşıyıcılar, akışlar ve kaynaklar olarak kategorize etmiştir. Onlar, taşıyıcıları, yönetim düşüncelerini ambalajlayarak yayan organize aktörler; akışları, yönetim düşüncelerinin yayımının yollarını göstermek ve kaynakları ise, yönetim bilgisinin kaynağını ifade etmek şeklinde tanımlamaktadırlar. Yönetim bilgisini icra eden, sağlayan ve yayan bir role sahip söz konusu bu aktörleri, yönetim danışmanları, işletme okulları ve yönetim basını şeklinde örneklendiren Sahlin-Andersson ve Engwall (2002), söz konusu bu taşıyıcıların genişlemesiyle ve büyümesiyle birlikte, yönetim bilgisi arzının da büyüdüğünü iddia etmektedirler. Bu çalışmada da, Batılı yönetim merkezlerinden birinde faaliyet gösteren Urwick Orr and Partners International danışmanlık şirketinden bir çevre ülke olan Türkiye'de faaliyet gösteren Türk Hava Yolları'na ve bu bağlamında ülkemize yönelik bir yönetim bilgisi transferi sürecindeki taşıyıcılar, o dönemdeki ekonomi-politik bağlam analize katılarak aktör merkezli tarihsel bir yaklaşımla incelenmiştir.

\section{3. İlgili Yazın: Yönetim Bilgisinin Merkezden Çevreye Transferi}

Yönetim bilgisinin transferi yazını hayli gelişmiş ve geniş kapsamlı bir yazın görünümü vermekle birlikte; daha önce de ifade edildiği üzere yönetim bilgisinin merkezden çevredeki bağlamlara transferi görece daha az ilgi görmüştür. Söz konusu bu görgül ilgi azlığına karşın, yazında farklı bağlamlara yönetim bilgisi (ve yönetim danışmanlığı) transferine ilişkin zengin olmamakla birlikte, ilgi çekici bir literatür oluşmuş bulunmaktadır.

Bu yazına önemli katkılarda bulunan çalışmalardan birinde, Frenkel ve Shenhav (2003), İsrail'e verimlilik artışı sağlayan üretim modellerinin transferini ilki Britanya kontrolündeki koloni dönemi ve ikinci ise bağımsızlık sonrası teknik yardıma dayalı Amerikanizasyon olmak üzere incelemişler ve sonuç olarak her iki dönemde de emperyal saiklerle hareket eden gönderici ülkelerin koloni olarak görülen İsrail'e en iyi yol olarak düşündükleri modelleri ihraç ettiklerini belirtmişlerdir. Frenkel (2005) bir diğer çalışmasında ise, Amerikan kaynaklı iki yönetim modeli olan Bilimsel Yönetim ile İnsan ilişkileri yaklaşımlarının İsrail'e yalnızca teknik olarak değil kültürel tercüme ve yorumlamaya dayalı ithalinde, devletin o dönemki politik ihtiyaçları ve ilişkilerinin oldukça önemli bir rol oynadığının altını çizmiştir. İsrail'deki bir diğer çalışmada da, yine devletin taşıyıcı olarak rolünü vurgulaması bağlamında, Kalev vd. (2008), Bilimsel Yönetim yaklaşımın unsurlarından olan ve emek ve sermaye grupları ile endüstri mühendisleri tarafından reddedilen ortak verimlilik konseylerinin (joint productivity councils) yayılımında, devlet, emek ve sermayeyi ikna edecek ve İsrail devletinin ve ulusunun kurtuluşunun ön koşulunun verimlilik olduğuna dayalı ahlaki bir söylemle birlikte kamu politikalarını hayata geçirmiştir. Arjantin'e popüler yönetim bilgisi ve modellerinin ithalini sorgulayan Gantman ve Parker (2006) ise, yönetim bilgisi ve guru modalarının transferinde ana taşıyıcı aktörlerin yerel yönetim akademisyenleri olduğunu ifade etmişlerdir.

Yönetim bilgisinin merkez-çevre arasındaki yolculuğuna ilişkin bilgi birikimine, belirli bir müddet sonra bu konuya mahsus özel sayılar da katkı sağlamıştır. 2008 yılında International Studies of Management \& Organization dergisinin yönetim bilgisinin çevre ülkelere transferine ilişkin görgül incelemeler içeren özel sayısı, önemli katkılar getirmiştir. Özel sayıdaki makaleler- 
den ilkinde, Srinivas (2008), Hindistan'a ABD kökenli yönetim bilgisinin ithalinde ana taşıyıcı aktörün Ford Vakfı ve bu vakfın Hindistan'da kurduğu yerel yönetim enstitüleri olduğunu; transfer sürecinin ilk aşamalarında bir taklit söz konusu iken, ikinci aşamada sayıca artan ve çoğalan yerel yönetim enstitüleri vasıtasıyla söz konusu küresel yönetim bilgisi için yerel kültürel karşılıkların üretildiğini belirtmektedir. Frenkel (2008), ABD kökenli İnsan İlişkileri yaklaşımına dayalı yönetim ideolojisinin (managerialism) sendikaların muhalefetine rağmen İsrail'e transferinde ABD’li uzmanlar ile onların İsrailli muadillerinin önemli bir rol oynadığını söylemektedir. Özel sayıdaki çalışmalardan bir diğerinde, 1990'lı yıllarda kurumsal sosyal sorumluluğun "Batıı" bir çevre ülkesi olan Avustralya'ya ithalinde finansal piyasaların ve uluslararası çevresel yönetim standartlarının rolü vurgulanırken (Wailes ve Michelson, 2008); diğer bir çalışmada ise yeni kamu yönetimi pratiklerinin Çin'e transferinde Britanyalı bir kültür kurumu olan British Council'in önemli bir taşıyıcı olduğunun altı çizilmektedir (Kerr, 2008). Özel sayıda yer alan son makalede ise, Erçek ve Say (2008), Türkiye'de Toplam Kalite Yönetimi'nin yayılımında başat aktörün KALDER olduğunu ve derneğin TKY söyleminin retoriklerini ülkenin ekonomi-politik bağlamına göre sürekli olarak güncellediğini bulgulamışlardır.

Buraya değin özetlenmeye çalışılan yazına ek olarak, yönetim bilgisinin merkezden çevreye transferinde kendi de bir yönetim bilgisi olan yönetim danışmanlığı ile söz konusu bu bilginin taşıyıcıları olan yönetim danışmanlarının (Frenkel ve Shenhav, 2012) rolüne ilişkin henüz gelişmekte de olsa bir yazın oluşmaktadır. Bu yazın kapsamında, Mir vd. (2009), ABD'li bir çok-uluslu şirketin Hindistan'daki yerel iştirakinde, ABD kökenli yönetim tekniklerinin transferi ve meşrulaştırılmasında yabancı yönetim danışmanlarının rolünü vurgularken; Wang (2009) ise, Çin'de yabancı yönetim danışmanlarının küresel yönetim bilgisi ithaline yönelik girişimlerinin piyasa ve firma düzeyinde çoğunlukla olumlu bir etkisi olduğunu belirtmektedir.

Söz konusu yönetim bilgisi transferi sürecinde yönetim danışmanlarının rolü tarihsel analizlere de konu olmuştur. Bunun önemli bir örneğini Pozzi'nin (2012) çalışması teşkil etmektedir. İtalya'nın devlet sahipliğindeki petrol şirketi ENI'nin 1956-1965 yılları arası ABD'li Booz Allen and Hamilton adlı danışmanlık firmasından örgütsel yenilikler için aldığı hizmetleri tarihsel kaynaklara dayalı bir şekilde analiz eden Pozzi (2012), söz konusu danışmanlık hizmetinin ABD'nin Marshall Planı vasıtasıyla İtalya'ya verdiği teknik yardım kapsamında alındığını ve bu her iki ülke hükümetinin yakından müdahil olduğu süreçteki en önemli taşıyıcının ABD Teknik Yardım ve Verimlilik Programı (US Technical Assistance and Productivity Program) tarafından desteklenen ve İtalyan hükümetinin bir organı olan Verimlilik Ulusal Komitesi (Comitato Nazionale per la Produttività) olduğunu belirtmektedir. Merkez-çevre ayrımı bağlamında, daha ilginç bir analize soyunan Cwiklicki ve Alcouffe (2012) ise, 2. Dünya Savaşı sonrası yönetim bilgisinin coğrafyası bağlamında ikincil bir merkez olarak nitelendirdikleri Fransa'dan bir çevre ülkesi olan Polonya'ya yönetim bilgisinin transferini, dönemin ünlü yönetim danışmanı Henri Bernaténé'nin B-G grafiğinin yayılımı bağlamında incelemişlerdir.

Yazın değerlendirmesi bağlamında, son olarak yönetim danışmanlığı faaliyetleri üzerinden gerçekleştirilen ve bu süreci tarihsel olarak inceleyen sınırlı sayıdaki yerli yazın eseri de incelenmiştir. Bu çalışmalardan birinde, Topal vd. (2012), Tanzimat dönemindeki sanayileşme hareketlerini Hereke Halı ve Ipekli Dokuma Fabrikası örneği üzerinden incelemiş; bu bağlamda da, bir Fransız yönetim danışmanı tarafından işletmenin daha etkin ve verimli çalışabilmesi amacıyla bir nizamname hazırlanıp işletme sahiplerine sunularak fabrikanın yeniden yapılanması amacıyla bir danışmanlık faaliyeti gerçekleştiğini belirtmektedirler. Son olarak, Sümerbank örneği 
üzerinden, erken Cumhuriyet döneminde devletin kendi sahipliğindeki işletmelerin nasıl yönetileceğine ilişkin yönetim bilgisi ithalini ele alan Özen Aytemur (2010); bu doğrultuda biri akademik diğeri ise uygulamaya dönük olmak üzere iki ayrı bilgi kanalının etkili olduğunu vurgulamaktadır.

\section{Amaç ve Kapsam}

Çalışmanın temel amacının, Türk Hava Yolları danışmanlık vakası bağlamında Urwick Orr and Partners ve o dönem için onun yerel ortağı olan Türk Sevk ve Idare Derneği ilişkisinden hareketle, yönetim danışmanlığı faaliyetlerinin gelişiminde uluslararası aktörlerle yerel ortakları arasındaki ilişkilerin incelenmesi olduğu söylenebilir. Çalışmada ayrıca, yönetim danışmanlığı faaliyetlerinin Türkiye'deki tarihsel gelişimine ve bu bağlamda da işletmecilik ve yönetim tarihi yazınına katkı yapmak da hedeflenmektedir. Bu amacı gerçekleştirebilmek adına, araştırmada kapsam olarak Urwick Orr and Partners danışmanlık şirketinin Türk Hava Yolları́na 1967-1971 yılları arasında yapmış olduğu Re-Organizasyon adı altındaki (Türk Hava Yolları A.O. 1968 Yıllık Rapor, 1969) yönetsel ve örgütsel içerikli ve hayli geniş kapsamlı danışmanlık faaliyetleri belirlenmiştir.

\section{Veri ve Yöntem}

Çalışmanın amacını gerçekleştirmeye yönelik olarak hayli geniş kapsamlı ve çeşitlendirilmiş tarihsel bir veri seti derlenmiştir. Söz konusu veri seti, büyük oranda ulusal olarak TBMM Kütüphanesi, Milli Kütüphane, Kalkınma Bakanlığı Kütüphanesi, Boğaziçi Üniversitesi Kütüphanesi, iBB Atatürk Kitaplığı ve Başbakanlık Cumhuriyet Arşivi'nde yapılmış taramalardan oluşmakta olup; aynı zamanda sınırlı sayıda materyalle olsa da Türk Hava Yolları arşivi ve Türk Sevk ve Idare Derneği arşivi ile zenginleştirilmiştir. Bu taramalarda Ford Vakfı/Foundation, Sevk ve Idare Derneği/Turkish Management Association, Sevk ve Idare Geliştirme Merkezi, Urwick Orr and Partners, Türk Hava Yolları/Turkish Airlines gibi proje paydaşlarına yönelik isimler yanında reorganizasyon, rasyonalizasyon, müşavirlik ve danışmanlık benzeri anahtar sözcükler de kullanılmıştır. Benzer şekilde, kamuya açık kütüphanelerde yer alan Türk Hava Yolları'nın yıllık raporları başta olmak üzere söz konusu danışmanlık hizmetine ilişkin bilgi içeren raporlara ve dokümanlara da ulaşılmaya çalışılmıştır. Aynı hususta, Türk Sevk ve Idare Derneği'nin yayın organı olan ve daha önce yönetim tarihi ile ilgili görgül çalışmalara konu olan (Üsdiken vd., 1998) Sevk ve idare Dergisi'nde de söz konusu danışmanlık faaliyeti ile ilgili tarama yapılmıştır. Ayrıca, danışmanlık faaliyetinin aktörlerinden biri olan Türk Sevk ve Idare Derneği'ne ilişkin olarak 23 Kasım 2015 tarihinde "Yönetim Alanında Kayıp Bir Aktör: Türk Sevk ve Idare Derneği" temasıyla gerçekleştirilen III. İşletmecilik Tarihi Çalıştayı'ndaki tebliğler de veri setine dahil edilmiştir. Son olarak, özellikle işletmecilik tarihi yazımında, arşiv kaynaklarına ulaşılamaması veya arşiv kaynaklarından yeteri kadar yararlanılamaması noktasında önemli bir kaynak olduğu zikredilen (Hansen, 2004) gazete haberlerinden de yararlanılmış ve bu doğrultuda Milliyet ve Cumhuriyet gazetesi arşivinde de taramalar yapılmıştır. Son olarak, projenin gerçekleştirildiği dönemde Türk Sevk ve İdare Derneği'nde uzman olarak görev yapan Ergun Zoga, derneğin yayın organı olan Sevk ve İdare Dergisi yayın kurulu üyesi Ege Cansen ve projede çalışmış olan Sevk ve İdare Geliştirme Merkezi uzmanı Ali ihsan Poyraz ile yarı yapılandırılmış mülakatlar gerçekleştirilmiştir. Nitel çalışmalarda, derlenen nitel veriler görüşme, gözlem ve belge incelemesi gibi bir veya birden çok yaklaşımla elde edilebilmektedir (Gephart, 2004:458). Bu çalışma kapsamında da, araştırma sorusunu cevaplayabilmek için yarı-yapılandırılmış şekilde gerçekleştirilen görüşmelerden, araştırılan olgu ile ilgili çok çeşitli dokümanlardan, ulusal yazılı basında yer alan haberler- 
den oluşan çok geniş, kapsamlı ve çeşitlendirilmiş bir veri setinden yararlanılarak veri nirengilemesi (data triangulation) yapılmıştır. Genel olarak nitel veri analizi, nitel verilerden bütüncül, anlamlı ve sembolik bir yapı oluşturma sürecidir (Kabakçı Yurdakul, 2016:2). Bu bağlamda, geniş ve kapsamlı veri seti ile tarihsel analize dayalı bir anlatı (narrative) (Erçek ve Günçavdı, 2016) inşa edilmiştir. Smith ve Weed (2007) de, anlatı analizinin özellikle pozitivist paradigmanın hakimiyetindeki alanlarda yorumlamacı bir nitel araştırma formu olarak çeşitli olanaklar sunduğunu belirtmektedir. Buna ek olarak, anlatı analizinin çalışmanın üzerine inşa edildiği sorunsal ve derlenen veriler bağlamında açımlanabilmesi imkânı da önemlidir. Analiz yaklaşımında subjektif anlamanın önüne geçmek için derlenmiş olan çeşitlenmiş veriler karşılaştırmalı ve çapraz bir okumaya tabi tutulmuştur.

\section{Bulgular}

Araştırma bulgularının sunumunda, Reay vd.'nın (2019) önerdiği ve daha çok mülakat ve arşiv materyali gibi verilerin kullanıldığı geçici evreler (temporal phases) yaklaşımı benimsenmiştir. Bu yaklaşım bağlamında araştırılan olguya ilişkin geçici bir anlatı inşa edilmektedir. Bu yaklaşımın en önemli özelliği, bulguların bütünlügünü sağlayan anlaşılır bir anlatı üretilmesine imkân vermesidir (Reay vd., 2019:208).

\subsection{Urwick Orr and Partners'ın Türk Hava Yolları'ndaki Danışmanlık Faaliyetleri (1967- 1971) \\ Urwick Orr and Partners International firması tarafından 1967-1971 yılları arasında Türk Hava Yolları'na yönelik olarak gerçekleştirilen danışmanlık faaliyetleri, söz konusu faaliyetlerin arka planı ve gerçekleştiği bağlam ile rol oynayan ve bu bağlamda yönetim bilgisinin transfe- rinde taşıyıcılık görevi üstlenen aktörlerin yanı sıra bu faaliyetlerin içeriği ve sonuçları bağla- mında bir anlatı kurgulanmıştır.}

\subsubsection{Danışmanlık Faaliyetlerinin Bağlamı ve Arka Planı}

1967 ile 1971 yılları arasında, Urwick Orr and Partners International firmasının Türk Hava Yolları'na yönelik olarak gerçekleştirdiği danışmanlık faaliyetlerini anlamak ve açıklamak üzere, öncelikle dönemin ekonomi-politik bağlamını dikkate almak ve söz konusu bu faaliyetlerin ve danışmanlık hizmetinin arka planını bu çerçevede yorumlamak gerekmektedir. Kimilerine göre, Avrupa ekonomilerinin her açıdan bir tür "Amerikanizasyon"u (Kipping ve Bjarnar 1998; Djelic, 1998) olan bir girişimle, II. Dünya Savaşı'nın muzafferi unvanına sahip ABD, savaştan oldukça kötü etkilenmiş ve her açıdan harap olmuş Avrupa'yı "kalkındırmak" amacıyla yürürlüğe koyduğu Marshall Planı yardımlarıyla Avrupa ülkelerinin büyük çoğunluğunun ekonomilerini şekillendiren adımlar atmıştır. Tüm Avrupa'da olduğu gibi başlangıçta söz konusu yardımların dışında kalan ve fakat daha sonra programa eklemlenen Türkiye'de de, tarımdan ulaştırmaya kadar birçok sektörde dış yardım kaynaklı bir yeniden düzenlemenin varlığı söz konusudur (Dik, 2008). Söz konusu yardımların organize edilmesi ve yürütülmesi için alıcı ülkelerde ABD elçiliklerine bağlı çeşitli misyonlar ihdas edildiği gibi (Devlet Bakanlığı, 1952), faaliyetlerin koordinasyonu için hükümetlerarası düzeyde bir işleve sahip ve bu bağlamda söz konusu yardımın organize edilmesi ve yönetim bilgisi ile modellerinin transferindeki mekanizmada önemli bir rol oynayan Avrupa Verimlilik Ajansı (European Productivity Agency) ve Avrupa Ekonomik İşbirliği Örgütü (Organization for European Economic Cooperation-OEEC) olarak kurulan ve bugün Ekonomik Kalkınma ve İşbirliği Örgütü (Organisation for Economic Co-operation and Development$O E C D$ ) olarak bildiğimiz kuruluşlar da oluşturulmuştur (Boel, 2003). İşte bu çalışmada da, Urwick 
Orr and Partners'ın Türk Hava Yolları'ndaki danışmanlık faaliyetleri hususunda önemli birer taşıyıcı ve/veya aracı olan ve yerli yazındaki çalışmalarda bu rolleri ele alınmayan Avrupa Verimlilik Ajansı ile Avrupa Ekonomik İşbirliği Örgütü/Ekonomik Kalkınma ve İşbirliği Örgütü’nün etkisi de ortaya konulacaktır.

Danışmanlık faaliyetlerinin ortaya çıktığı politik bağlamı anlamak adına, TBMM'de konu ile ilgili çıkarılan mevzuatın tarihsel olarak incelenmesi önem arz etmektedir. Buna göre, Urwick Orr and Partners'ın Türk Hava Yolları'na yönelik danışmanlık hizmetini, o dönem KiT'lerin sorunlarının tanımlanarak yeniden düzenlenmelerine ilişkin daha geniş kapsamlı bir projenin bir parçası olarak ele almak mümkündür. Bu bağlamda, 1960'lı yıllarda benimsenen planlı ekonomi anlayışı, KiT’lerin yeniden gözden geçirilmesini gündeme getirmiştir (Aksoy, 1994:18). İşte tam da bu noktada, Avrupa Verimlilik Ajansı ile Avrupa Ekonomik İşbirliği Örgütü/Ekonomik Kalkınma ve İşbirliği Örgütü gibi uluslararası taşıyıcıların devreye girmesine imkan veren ve kamu iktisadi teşebbüslerini her bakımdan incelemek ve alınması gereken tedbirleri sağlamak için ABD'nin teknik yardımına bağlı ABD Uluslararası Kalkınma Ajansı (US Agency for International Development-AID) ve OEEC/OECD uzmanlarının ülkeye gelerek bazı KiT'lerde incelemeler yapmasına olanak sağlayan (Aksoy, 1994) 154 sayılı kanun 6 Aralık 1960 tarihinde çıkarılmıştır (154 Sayılı Kanun, 1960). Bu kanun uyarınca, teknik yardım kapsamında uzmanlar temin edilerek kamu iktisadi teşebbüslerinde incelemelerde bulunarak hem OECD ve dönemin hükümetine hem de müstakil olarak her bir ilgili KiT'e sunulmak üzere Kamu iktisadi Teşebbüslerine Ait Genel Rapor ve Kamu iktisadi Teşebbüslerine Ait Özel Raporlar adlı raporlar hazırlanmış ve alınması gerekli tedbirler açıklanmıştır. Özellikle Maliye Bakanlığı tarafından iki cilt olarak basılan ve aralarında Türk Hava Yolları’nın da bulunduğu kamu iktisadi teşebbüslerine ilişkin Kamu iktisadi Teşebbüslerine Ait Özel Raporlar, kütüphane sorgulamalarından anlaşıldığı üzere önce İngilizce olarak ayrı basım şeklinde yayınlanmış (Smith, 1961) ve daha sonra yine İngilizce dilinde üç cilt olarak basılmıştır (Maliye Bakanlığı, 1961a). Türkçe olarak basılan iki ciltlik Kamu iktisadi Teşebbüslerine Ait Özel Raporlar (Maliye Bakanlı̆̆ı, 1961b) yayını da bu üç ciltlik yayının birebir çevirisidir. Raporun önsözünden anlaşıldığı üzere, inceleme ve her bir KiT’e ilişkin rapor sunma faaliyetleri 154 sayılı yasanın 17. maddesi uyarınca gerçekleştirilmiş ve kapsam olarak aşağıdaki KiT'ler belirlenmiştir (Smith, 1961:1):

- Şeker Fabrikaları Grubu,

- Kâğıt ve Selülöz Grubu,

- Et Balık Grubu,

- Kömür Grubu,

- Zirai Donatım Grubu,

- Azot Sanayii Grubu,

- Devlet Demir Yolları,

- Petrol İşleri Grubu,

- iller Bankası,

- Sümerbank Grubu,

- Emlak Bankası,

- Makine Kimya Grubu,

- Türk Hava Yolları,

- Karabük Grubu,

- PTT. 
Teknik yardım kapsamında KiT’lerde incelemeler yapan uzmanların bakış açılarını oldukça güzel yansıtan raporlardan Türk Hava Yolları'na ilişkin olanının, Avrupa Ekonomik İşbirliği Örgütü'ne bağlı Avrupa Verimlilik Ajansı adına danışman olarak görev yapan British European Airways havayolunun kaptan pilotlarından Holroyd Smith tarafından 10 Nisan 1961 ile 15 Mayıs 1961 tarihleri arasındaki incelemelere binaen kaleme alındığı anlaşılmaktadır (Smith, 1961). Öncelikli olarak acilen THY ve Ulaştırma Bakanlığı'na uluslararası bir sivil havacılık danışmanı atanmasını ve bunun da ABD Teknik Yardım Ajansı vasıtasıyla mümkün olabileceğini belirten Smith (1961:5), raporunda Türk Hava Yolları'nın yeniden düzenlenmesi (reorganization) için 15 maddelik içeriğe sahip bir öneride bulunmuştur (Smith, 1961).

Bu bağlamda, 21 Mart 1964'te ise, hem Türk Hava Yolları hem de diğer KiT'lere ilişkin olarak Kamu Iktisadi Teşebbüslerine Ait Özel Raporlar'da yer alan yeniden düzenlenme ve ıslah önerilerini yerine getirmek için 440 sayılı kanun çıkarılmıştır (Aksoy, 1994). Temel amacı (440 Sayılı Kanun, 1964:975);

"iktisadi Devlet Teşekkülleriyle müesseseleri ve iştiraklerin ulusal ekonomimize faydalı olabilmesi için özerk bir tarzda, Karma ekonominin kurallarına ve ekonomik gereklere uygun olarak yönetilmelerini, kârlılık ve verimlilik anlayışı içinde çaıısmak ve sermaye birikimine yardım etmek suretiyle daha fazla yatırım kaynağı yaratmalarını ve bu amaca ulaşmak için denetlenmelerini sağlamak"

olarak ifade edilen 440 sayılı kanun kapsamında, KiT'lerde incelemelerde bulunan teknik yardım uzmanlarının raporlarında belirttikleri önerileri hayata geçirmek için Maliye Bakanlığı'na bağıı olarak, Maliye, Sanayi ve Ticaret Bakanlıkları ile Devlet Plânlama Teşkilâtı'nı, Yüksek Denetleme Kurulu'nu ve Devlet Personel Dairesi'ni temsil eden 6 üyeden oluşa bir iktisadi Devlet Teşekküllerini Yeniden Düzenleme Komisyonu teşkil edilmiştir (440 Sayılı Kanun, 1964:983).

İşte tam bu noktada, yasal altyapı da hazırlandıktan sonra söz konusu yeniden düzenleme çalışmalarının kim tarafından gerçekleştirileceği gündeme gelmiştir. Bu aşamada, OECD ön alarak devreye girmiş ve yönetim bilgisinin üretildiği merkez ülkelerde yer alan danışmanlık firmalarının yeniden düzenleme kapsamındaki faaliyetleri gerçekleştirmesi için Türkiye Cumhuriyeti nezdinde girişimlerde bulunmuştur. Kalkınma Bakanlığı kütüphanesinde yer alan ve Türkiye'nin $O E C D^{\prime}$ nin finanse ettiği projeler ile ilgili toplantılarına ilişkin belgelerde söz konusu husus açık bir biçimde görülmektedir. Buna göre, $O E C D$ nezdindeki toplantılarda Türk heyetini OECD Daimî Temsilciliği Baş Delegesi olarak temsil eden Cahit Kayra'nın hükümete hitaben göndermiş olduğu rapordan, söz konusu yeniden düzenleme faaliyetlerine ilişkin yapılacak fizibilite çalışmalarının görüşülmesi hususunda, "toplantılarda kararlaştırılı̆̆ı gibi, her ilgilice kabul edilebilecek müşavirlik firmalarının bir listesinin”" (Kayra, 1965:23) hazırlandığı anlaşılmaktadır. Benzer şekilde, yabancı müşavirlik firmalarının gelişini meşrulaştırmak amacıyla, OECD’nin teknik işbirliğinden sorumlu Kalkınma Birimi'nin (Development Department) Teknik Yardım Programı kapsamında London School of Economics and Political Science profesörlerinden William A. Robson'a hazırlattığı 56 proje numaralı raporunda; "KiT'lerin hiçbirinin söz konusu yeniden düzenleme faaliyetleri kapsamındaki uzun dönemli planlama, yıllık yatırım programları ve müstakil projeleri organize edecek yeterlilikte yönetsel koordinasyon, profesyonel beceri ve tecrübeye sahip özel bir biriminin bulunmadığı” vurgulanarak (Robson, 1965:4-5) danışmanlık faaliyetlerinin hayatiyeti vurgulanmakta ve meşruluğu pekiştirilmektedir. 


\subsubsection{Danışmanlık Faaliyetinin Ortaya Çıkışı ve İçeriği}

Urwick Orr and Partners International firmasının Türk Hava Yolları'na yönelik olarak gerçekleştirdiği danışmanlık faaliyeti, söz konusu bu bağlamda ortaya çıkmış ve KiT’lerin yeniden düzenlenmesi ve re-organize edilmesi faaliyetlerinin bir parçası olarak 1967 yılında ilk adım atılmıştır. Buna göre, Urwick Orr and Partners International müşavirlik firmasından hizmet alınacak olup; danışmanlık faaliyetinin mali külfeti için daha önce ifade edildiği üzere o dönem yönetim bilgisinin transferi bağlamında önemli bir aracı olan $O E C D^{\prime}$ den malî külfeti karşılamak için 100.000 ABD doları tutarında üç yıllık kredi alınmıştır (Nergiz, 2008:187). Esasında, Türk Hava Yolları'nın yıllık raporları incelendiğinde, 1967 yıllında uygulamaya geçen söz konusu bu danışmanlık faaliyetinin evveliyatının 1966 yılına dayandığı görülmektedir (Türk Hava Yolları 1966 Yıllık Rapor, 1967:23):

"Bütün bunlara ilaveten OECD programlarından istifade edilerek yine Ortaklığa hiçbir mali külfet tahmil edilmeksizin yabancı uzmanlar celbedilmesi hususunda da gerekli tedbirler alınmış bulunmaktadır. Peyderpey gelmekte olan bu yabancı uzmanların tamamlanmasını müteakip geniş bir reorganizasyon faaliyetine girişilecektir."

Türk Hava Yolları́nın izleyen yıllardaki yıllık raporları yakından incelendiğinde, söz konusu danışmanlık faaliyetinin alınmasında ve bu bağlamda yönetim bilgisinin transferinde Saint-Martin'in (2012) hükümetlerin yönetim danışmanlığı hizmetine ihtiyacı vurgusunu destekler bir biçimde, önemli aktörlerden birinin Türkiye Cumhuriyeti hükümeti olduğunu anlamaktayız (Türk Hava Yolları 1968 Yıllık Rapor, 1969:4-5):

"Ortaklığımızın arzulanan Hava Yolu İşletmeciliği seviyesine ulaşabilmesi için Cumhuriyet Hükümeti'nin tasvibi ve Devlet Planlama Müsteşarlığı aracılığı ile Ekonomik Gelişme Iç̧in İşbirliği Teşkilatı (OECD) ve Türk Sevk ve Idare Merkezi (TSiGM)'nin alaka ve yardımları neticesi 1967 sonlarında başlıyan ${ }^{3}$ tetkik çalışmaları bütün 1968 yılı içinde devam etmiş ve uzmanların 5 ana istikamette hazırladıkları raporlardan 4'ü Ortaklığımıza verilmiştir."

Yukarıdaki pasajdan da anlaşıldığı üzere, yönetim bilgisinin transferindeki yerel aracılar arasında Devlet Planlama Teşkilatı Müsteşarlığı da bulunmaktadır. Zira, 2011 yılında tümüyle Kalkınma Bakanlığı'na devredilen DPT’nin süreçteki rolünü anlamak adına Kalkınma Bakanlığı kütüphanesinde gerçekleştirilen taramalardan, Urwick Orr and Partners International adlı danışmanlık firması ile DPT'nin yakın ilişkide bulunduğu ve ilgili firmanın THY örneğine benzer şekilde OECD kredisi ve aracılığı ile THY dışında Toprak Mahsulleri Ofisi ile Türkiye Demir Çelik İşletmeleri gibi o dönemin önemli KiT’lerine yönelik danışmanlık faaliyetlerinde de bulunduğu anlaşılmaktadır (Urwick Orr and Partners International, 1968).

Söz konusu hususa ek olarak, 1957 yılından 1974 yılına değin Türk Hava Yolları́na ortak olan ve bu sebeple yönetim kurulunda bir üye de bulunduran British Overseas Airways Corporation'ın varlığı da düşünüldüğünde, Türk Hava Yolları'na yönelik danışmanlık faaliyeti için İngiliz Urwick Orr and Partners International firmasının seçilmiş olması şaşırtıcı olmasa gerektir. Daha önce ifade edildiği üzere Urwick Orr and Partners International'ın bu danışmanlık faaliyetindeki yerel ortağı ise Türk Sevk ve Idare Geliştirme Merkezi'dir (Nergiz, 2008:187). Urwick Orr and

\footnotetext{
${ }^{3}$ Metindeki direk alıntılarda yer alan bu vb. yazım yanlışları ve günümüzden farklı kullanımlar, dönemin ruhunu yansıtması bağlamında değiştirilmeyerek muhafaza edilmiştir.
} 
Partners International adlı danışmanlık firması, Urwick Orr and Partners Limited adıyla 6 Temmuz 1934'te Lyndall Urwick ile Leslie Orr tarafından İngiltere'de kurulmuştur (Brech, Thomson ve Wilson, 2010:93). Bir aktör olarak Türk Sevk ve İdare Derneği de 1962 yılında dönemin önde gelen iş adamlarının girişimiyle kurulup 1979 yılına kadar Türk iş sistemi içerisinde bilgi transferi faaliyetlerine devam eden önemli bir aktördür. Türk Sevk ve İdare Derneği özellikle 1966 yılında kuracağı Sevk ve İdare Geliştirme Merkezi vasıtasıyla yönetim danışmanlığına odaklanarak temelde yönetim bilgisinin Türkiye bağlamına transferi rolünü üstlenmiş bir dernektir (Kurt, Özcan ve Özkal, 2010). Türk Sevk ve Idare Geliştirme Merkezi, müşavirlik faaliyetlerinde bulunmak üzere Türk Sevk ve Idare Derneği'ne bağlı olarak Ocak 1966'da kurulmuştur. Buna göre merkez, "iş idaresi konusunda sanayie bilgi ve maharet sağlıyacak bir hizmet organizasyonu"dur. Merkezin amaçları arasında; "çeşitli iş kollarında faaliyette bulunan özellikle orta ve küçük çaptaki sınai ve ticari işletmelere profesyonel sevk ve idare müşavirliği hizmetleri yapmak, teknik yardımda bulunmak ve idareciler için özel kurslar organize etmek" (Özsoy, 1966:11) bulunmaktadır. Danışmanlık faaliyeti için yerli ortak olarak Türk Sevk ve Idare Geliştirme Merkezi'nin seçilmesi şaşırtıcı olmasa gerektir. Zira hem o dönem Türk Sevk ve Idare Geliştirme Merkezi'nin Türkiye'deki kelimenin tam anlamıyla ilk ve tek profesyonel yönetim danışmanlığı örgütü olmasının (Üsdiken, 2015) hem de merkezin bağlı bulunduğu Türk Sevk ve Idare Derneği ile bireysel olarak Lyndall Urwick ve kurumsal olarak da Urwick Orr and Partners ile derneğin kuruluşundan itibaren ilişkileri bulunması etkilidir. Bu bağlamda, söz konusu ilişkiye örnek olarak, Lyndall Urwick' in biyografisinden derneğin kuruluşundan bir yıl sonra, kendisinin Türkiye'ye bir ziyaret gerçekleştirdiğini (Brech vd., 2010:175) öğrenmekteyiz. Dahası Urwick'in bu ziyaret kapsamında 29 Mart 1963'te Sevk ve Idare Etme Bir Ilim Mi, Yoksa Bir San'at Mıdır? (Managing Science or Art?) ve 30 Mart 1963'te Yüksek Sevk ve Idare Nedir? (What is Top Management) başlıklı iki konferansının Türkçeleştirilerek dernek tarafından yayınlandığı (Urwick, 1965) görülmektedir. Dahası, Türk Sevk ve Idare Merkezi'nin kuruluşu ile ilgili önemli bilgilere ve yazılara yer verilen Sevk ve idare Dergisi'nin ilk sayısındaki yazısında bilgi veren merkez uzmanlarından Fahir Özsoy, Urwick Orr and Partners ile İstihsal Müşavirliği için teknik anlaşmaya varıldığını ve söz konusu firmada sevk ve idare eğitimi görmek üzere 3 kişilik bir ekibin 1965 yılı Eylül ayında İngiltere'ye gönderildiğini belirtmektedir (Özsoy, 1966:12). Buna ek olarak, Haluk Erkmen de, Urwick Orr and Partners International firmasının eğitim merkezi olan Urwick Management Center' daki sevk ve idare müşavirliği kursundaki eğitimi süresindeki intibalarını nakletmiştir (Erkmen, 1966). Benzer şekilde, Urwick Orr and Partners müşavirlerinden olduğu yazısındaki tanıtıcı bölümler ile detaylı bilgilerden anlaşılan Lee Bedford ise, Türkiye için o dönem çok yeni bir kavram olan Sevk ve İdare Müşavirliği'nin önemine değinirken, daha sonra THY örneğinde de uygulaması görülecek olan ve müşavirlik faaliyetinin temelde ön inceleme ve tatbik etme şeklinde iki aşamadan meydana geldiğini şöyle izah etmektedir (Bedford, 1966:15):

"Müşavir şirket genellikle ilerde müşterisi olacak firmanın iş durumu ile ilgili bir ön incelemede bulunur. Yapılması gereken işin -eğer müşavirlik hizmetinden yararlanılması tavsiye olunuyorsa- süresini ve bu işin sonucundan firmanın sağlıyacağı çıkarların belirtildiği bir teklif hazırlar. Müşteri bu teklifi ya kabul ya red eder veya değiştirir. Teklif edilen hususların kısmen veya tamamen kabul edilmesi halinde Müşavir, mutabık kalınan süre boyunca bu firma ile birlikte çalışır. Bu arada ileri sürdügü teklifte müşterisi için yararlı görülen değişikliklerin gerçekleşmesine yardım eder." 
Söz konusu yakın ilişkiyi, çalışma kapsamında yapılan yazılı basın taramasından da izlemek mümkündür. Buna göre, Türk Sevk ve Idare Merkezi'nin 1966 ile 1972 yılları arasında, "Sevk ve idare Müşavirliği Için Eleman Alınacaktır” başlığıyla verdiği ilanlarda (Milliyet, 1966); “... (m)üstakbel müşavirler ingiltere'ye gönderilecek, orada sevk ve idare müşaviri (Management Consultant) olarak yetiştirilmek üzere 4-5 aylık özel bir eğitime tabi tutulacaktır." ifadesi, yakın ilişkinin en somut göstergelerindendir.

Nihayetinde, bu kapsamda, Türk Sevk ve Idare Geliştirme Merkezi de danışmanlık sürecine dahil olmuş ve müşavirlik hizmetlerinin mali külfeti THY bütçesinden karşılanmak üzere (Türk Hava Yolları 1968 Yıllık Rapor, 1969:30), Türk Sevk ve Idare Geliştirme Merkezi ile Türk Hava Yolları arasında bir müşavirlik hizmeti mukavelesi imzalanmıştır. Bu mukavele, işletmenin kompüter (elektronik beyin) ihtiyacı analizi, uzun vadeli planlama-organizasyon yapısı-sevk ve idare geliştirme tatbikatı, eğitim ihtiyacı analizi, mali kontrol, iş değerlendirmesi ve liyakat takdiri olmak üzere 5 ayrı işi kapsamaktadır (Sevk ve İdare Dergisi, 1968:43). Türk Hava Yolları'nın yönetim kurulu karar defterlerini inceleyen Nergiz (2008:187), danışmanlık projesinin amacının THY'yi; “idarî, teknik ve işletmecilik yönlerinden modern hava taşıyıcıları seviyesinde, emniyetli, yolcularını memnun eden ve iktisadî çalışarak kâr eden bir işletme haline getirmek" olarak belirlendiğini belirtmektedir. Urwick Orr and Partners firması ile Türk Sevk ve Idare Geliştirme Merkezi uzmanlarının ortaklaşa yürüttüğü müşavirlik işleri, Türk Hava Yolları'nın 1968 yıllık raporunda kendine şöyle yer bulmuştur (Türk Hava Yolları 1968 Yıllık Rapor, 1969:30-31):

- Kompüter (Elektronik Bilgi İşleme Makinesi) kullanılması imkânı: Bu mevzuda, Urwick Orr and Partners International müşavirlik firmasının uzmanı olan Dr. C.V. Forrington Ortaklığımız nezdinde 29.2.1967 ve 2.2.1968 tarihleri ile, 19.3.1968 ve 12.4.1968 ve 3.6.1968 ile 7.6.1968 tarihleri arasında cem'an 9 hafta çalışıp THY'de, Kompüter kullanılması imkanlarını etüd etmiş (Computer feasibility) ve etüd neticeleri 20.6.1968 tarihli bir raporla Ortaklığımıza sunmuştur.

- Eğitim Ihtiyaçlarının Tespiti: Yine Urwick Orr and Partners International Müşavirlik Firması uzmanı Mr. L. Croocker 8.7.1968-27.9.1968 tarihleri arasında ceman 12 hafta, Türk Sevk ve İdare Geliştirme Merkezi uzmanlarından Yalçın Tiftik'le beraber THY'de Eğitim İhtiyaçlarının Analizi mevzuunda 27.9.1968 tarihli bir rapor sunmuşlardır.

- Mali Kontrol: Bu mevzuuda Urwick Orr and Partners International Müşavirlik firması uzmanı Mr. W. T. Holden, Türk Sevk ve İdare Geliştirme Merkezi uzmanlarından Abdülkadir Demir ile birlikte 1.4.1968-20.12.1968 tarihleri arasında ceman 34 hafta çalışmıştır. Abdülkadir Demir'den Mali Kontrol II-ikram Maliyetleri üzerine bir rapor, Mr. Holden'dan da bir ara rapor alınmıştır.

- Uzun Vadeli Plan ve Organizasyon: Urwick Orr and Partners International firmasında Mr. John F. Crawford 11.12.1967 tarihinden itibaren ortaklığımızda çalışmağa başlamış ve 2.11.1968 tarihinde ayrılmıştır. Bu çalışma devresi içinde 15 günlük senelik izin almış ve Türk Sevk ve İdare Geliştirme Merkezi uzmanlarından Oğuz Herkmen'le birlikte Uzun Vadeli Plan ve Organizasyon mevzuunda çalışmıştır. Etüd neticesi 4 ayrı rapor vermişlerdir.

- $\quad$ Iş̧ Değerlendirilmesi: Bu konuda yalnız Türk Sevk ve İdare Geliştirme Merkezi uzmanı Ali insan Poyraz 1968 yılı içinde 40 hafta çalışmak suretiyle Ortaklığımızda mevcut iş çeşitlerine uygun 4 değerlendirme planı geliştirmiş, bunlar 4 komite tarafından değerlendirilmiştir. Ancak ilk tahminde 320 çeşit iş kanısı ile tespit edilen 39 haftalık müddet, 
hakikatte 530 iş çeşidi olması dolayısı ile yetmemiş, çalışma temposu umulandan yavaş olmuştur. Bu yüzden ek bir mukavele ile bu işin tamamlanması hususundaki müracaatları tetkik edilmektedir. Şimdiye kadar 335 işin tahlili yapılmış, bunlardan 200'ünün değerlendirilmesi de tamamlanmıştır.

Danışmanlık projesinde görev alan merkez uzmanlarından Ali İhsan Poyraz da görev aldığı uzun vadeli planlama ve iş değerlendirilmesi çalışmalarına ilişkin olarak şunları belirtmektedir (Poyraz, 2019):

"Benim THY'de yaptığım ağırlıklı olarak iş tanımları, iş değerlemesi... Uzun vadeli planlama işlerinde de çalıştım ben... Organizasyonel birtakım çalışmalar yaptık. Zira o sıralarda $T H Y^{\prime}$ de çok fazla organizasyonel problemler vardı. Hiyerarşi açısından bozukluklar vardı. Bütün THY istasyonlarında çalıştık, oradaki işleri analiz ettik... Onlara hedefler koyduk."

Urwick Orr and Partners International ile Türk Sevk ve Idare Geliştirme Merkezi tarafından ortaklaşa yürütülen çalışmalar, özellikle bazı işler için büyük oranda, Bedford'un (1966) daha önce zikrettiği üzere ön incelemeye dayalı raporlama ve söz konusu raporlar doğrultusunda tatbikat diye özetlenebilen dönemin danışmanlık sürecini gözler önüne seren aşamalardan ilki olan raporlama kısmında kalmıştır. Buna göre, aslında 1968 yılında reorganizasyon çalışmaları kapsamında bir Yolcu Hizmetleri Müdürlügü kurulmasına karar verilen (Nergiz, 2008:188) faaliyetler, hazırlanan raporlardan ve iktisadi Devlet Teşekküllerini Yeniden Düzenleme Komisyonu'nun raporlarından istifade edilerek Muhasebe Müdürlüğü yerine Muhasebe ve Mali Işler Müdürlüğü kurulması ile önemli bir başlangıç yapmıştır. Kompüter kullanılması bağlamındaki önemli bir adım ise, bu müdürlük bünyesinde işletmenin ihtiyacı olan bilgilerin süratle hazırlanıp, sıhhatli bir şekilde kullanılmağa amade kılınması ve el emeğinin tasarruf imkanlarını yaratacak kompüterleşme çalışmalarını yönetmek için bir Elektronik Bilgi işlemleri Müdürlüğü kurulmasıdır (THY 1970 Yıllık Rapor, 1971:39). Daha da önemlisi, 1970 yılında sürmekte olan yeniden yapılanma çalışmaları kapsamındaki danışmanlık hizmetlerini koordine etmek için Genel Müdür Yardımcısı Ertuğrul Alper'in başkanlığında (Nergiz, 2008:188) bir Reorganizasyon Tetkik ve Tatbik Komisyonu kurulması girişimi; söz konusu faaliyetlere şüphe ile bakılmasına ve daha hızlı bir ilerleme sağlanamaması noktasında denetçiler tarafından aşağıdaki gibi eleştiriler getirilmesine engel olamamıştır (THY 1970 Yıllık Rapor, 1971:5):

“... (T)ürk Hava Yolları'nı modern ve ileri bir hava işletmesi haline getirmek için teşkilatın yalnız fonksiyonlarının değil, organik bünyesinin de yeni ihtiyaçlara göre reorganize edilmesi ve böylece sevk ve idare tatbikatının geliştirilmesi gayesini güden ve fakat 1968 yılının ilk günlerinde başladığı halde tam neticelendirilmeyen yada hazırlanmış raporları tatbike konulmayan Reorganizasyon çalışmaları hakkında kesin bir karar ittihazı zaruridir. Eğer bu etüdler elverişli değil ise izahı yapılarak bir tarafa bırakılmalıdır. Bu takdirde aynı gayeyi başka yoldan temin edecek metodlu tedbirlere başvurulması icap edeceği görüşündeyiz."

1971 yııındaki yıllık rapordan İş Değerlendirme Çalışmaları'nın durumu ile ilgili olarak yaşanan gelişmelerin neler olduğunu öğrenmekteyiz. Buna göre, Türk Sevk ve Idare Geliştirme Merkezi, İş Değerlendirme Çalışmaları için 31.5.1971'de THY'ye nihai bir rapor sunmuştur. Bu bağlamda, İ̧̧ Değerlendirme Çalışmaları iki aşamada ele alınmış olup; ilk aşamada; "teşkilatın bün- 
yesindeki bütün işler ilmi ve objektif esaslara göre sistematik olarak analiz edilmiş ve bu analizlerden İş Tarifleri ile birlikte o işi icra etmekle görevli personelde aranacak bilgi ve maharet gereği ile fiziki ve manevi nitelikler ve sorumluluk dereceleri de ortaya çıkarılmıştır." Söz konusu çalışmaların izleyen aşamasında ise; "tarifleri meydana getirilen işler ağırlıklı puan sistemine göre kıymetlendirilmiş, ücret ve puan ilişkilerinin hesaplanmasına geçilerek 'Eşit İşe Eşit Ücret' ödenmesi ve böylece adil bir ücret sisteminin ortaya çıkarılması" hedeflenmiştir (THY 1971 Yıllık Rapor, 1972:29).

\subsubsection{Danışmanlık Faaliyetinin Sona Ermesi}

Söz konusu bu iş ve işlemlere karşın, Urwick Orr and Partners International ile Türk Sevk ve idare Geliştirme Merkezi'nin ortaklaşa olarak Türk Hava Yolları'na yönelik olarak gerçekleştirdikleri danışmanlık faaliyetinin kompüterleşme, mali kontrol ve reorganizasyon ile iş değerlendirmesi hususlarında bir nebze başarıya ulaşmış olarak kabul edilebileceği; buna karşın eğitim ihtiyaçlarının tespiti, iş değerlendirme kapsamındaki liyakat sistemi kurulması ve uzun dönemli planlama ile organizasyon gibi işlerde ise herhangi bir ilerleme sağlanamadığı anlaşılmaktadır. Örneğin, Nergiz (2008:187-188), söz konusu danışmanlık faaliyetinin, THY gibi üzerinde siyasî etkinin yoğun olduğu bir organizasyonda ne boyutta hayata geçirilebildiğinin tartışma konusu olacağını belirtmekte ve söz konusu politik etkiyi vurgulayarak özellikle İş Değerlendirmesi kapsamındaki "liyâkat takdiri" konusunun kolay kolay uygulanamayacağının altını çizmektedir. THY'nin 1973 yıllık raporunda da söz konusu işlerde neden ilerleme sağlanamadığına değinilerek muhtemel sebepler şöyle sıralanmıştır (THY 1973 Yıllık Rapor, 1974:68):

"Yıllardan beri çeşitli organizasyon gayretleri sarfedilegelmiştir. Ancak, çok çeşitli nedenlerle bu çabaların amaçlarına ulaşamadığı anlaşılmaktadır. Bu nedenlerin başlıcaları, idari gelenek ve alışkanlıklar, hiyerarşi içindeki çeşitli görevlerin belirli görevlilerle birlikte düşünülmeleri alışkanlığı, çeşitli meslek veya görev gruplarına mensup personelin THY içinde birbirlerini tamamlayan ekipler teşkil ettiklerini düşünmek yerine tenkitçi davranışları daha çok benimsemeleri, genel eğitim düzeyi, kazanılmış haklar, alt kademeler dâhil yöneticilerin liderlik yetenekleri, mevzuattan gelen veya sözleşmelerden gelen kısıtlamalar ve modern sevk ve idare yöntemlerinin iyi bilinmeyişi gibi noktalar etrafında toplanabilir."

Hem Nergiz'in (2008) tespitleri hem de yukarıda zikredilen sebepler düşünüldüğünde, projenin amacına ulaşamamasında o dönem Türk Hava Yolları'na hâkim bürokratik yapının önemli bir rol oynadığı söylenebilir. Ayrıca, Ali İhsan Poyraz da danışmanlık faaliyetlerinin akamete uğramasında "siyasi nüfuz alanı olarak görülen $T H Y$ 'deki genel müdür ve üst düzey yönetici değişikliklerinin danışmanlığı yap-boza çevirdiğini" (Poyraz, 2019) belirtmektedir. Nihayetinde, Türk Hava Yolları'nın izleyen yıllardaki raporları incelendiğinde gerçekten de bu faaliyetler ile ilgili somut adımlar atıldığı ve zikredilen sebeplerle beklenilen etkiyi yaratamayan danışmanlık hizmetleri için yeni bir arayışa girildiği ve bu kapsamda bilimsel açıdan da meşruiyeti hayli yüksek bir eğitim kurumu olan İstanbul Üniversitesi Işletme Fakültesi ile anlaşıldığı görülmektedir. Türk Hava Yolları'nın 1974 yılındaki raporunda yer alan ifadeler bu işbirliğinin kapsamını ifade etmektedir (THY 1974 Yıllık Rapor, 1975:13):

"Istanbul Üniversitesi İşletme Fakültesi ile bir anlaşmaya varılarak: Genel kadro sınıflandırılması, Personel seçimi, yerleştirme ve terfi, nakil politikalarının belirlenmesi, Liyakat takdir sisteminin kurulması, Norm kadro çalışmaları, Ücret yönetim esaslarının tespiti, Teşkilat ve El Kitabı'nın hazırlanması gibi konularda ortaklığın 
yeniden düzenlenmesine başlanmış bulunmaktadır. Yıl sonuna doğru çalışmaların biteceği ve Türk Hava Yolları A.O.'nun modern bir teşkilat ve sisteme kavuşacağına inanıyoruz."

Türk Sevk ve Idare Geliştirme Merkezi vasıtasıyla Urwick Orr and Partners müşavirlik firmasından alınan hizmetin asıl olarak neden sona erdiğine ilişkin arşiv taramaları ve çalışmada derlenen veriler müspet bir cevap verememektedir. Buna karşın, dönemin politik ve ekonomik bağlamı düşünüldüğünde, özellikle Kıbrıs Barış Harekâtı nedeniyle Türkiye ile Batılı ülkeler arasında gerilen ikili ilişkilerin (Coşkun, 2015), söz konuşu danışmanlık faaliyetlerinin sona ermesinde bir etkisi olduğu zikredilebilir. Zira, Kıbrıs Barış Harekâtı nedeniyle bozulan Türkiye-Büyük Britanya ilişkileri yalnızca söz konusu danışmanlık ilişkisini etkilememiş ve Türk Hava Yolları'nın yönetim kurulunda bir değişikliğe de sebebiyet vermiştir. Buna göre, 2 Mayıs 1974 tarihinde yapılan olağanüstü genel kurul sonrasında, yabancı yatırımı temsil eden İngiliz British Overseas Airways Corporation'ı temsil eden Gilbert Lee, Türk Hava Yolları yönetim kurulu üyeliğinden çıkarılmış ve 1977 yılında da, tam 20 yı önce yabancı sermayeye açılmış olan şirket, Maliye Bakanlığı'nın 17.2.1977 tarih ve 53315/6967 sayılı kararı ile tekrar millileştirilmiştir (THY, 2008:123). Türk Sevk ve İdare Derneği'nin ise, 1979 yılında dernek çalışanlarının sendikalaşma ve grev talepleri sebebiyle faaliyetlerine son verdiği belirtilmektedir (Kurt, Özcan ve Özkal, 2010). Araştırma kapsamında Ali İhsan Poyraz ve Ege Cansen ile yapılmış görüşmelerle de bu hususu destekleyici beyanlara yer verilmiştir. Dahası, 1972-1979 yılları arası Sevk ve İdare Geliştirme Merkezi genel müdür yardımcılığı ve genel müdürlüğü yapmış olan Ergun Zoga da derneğin sendikalılaşma problemlerinden dolayı kapandığını ifade etmektedir (Kurt, Özcan ve Özkal, 2010).

\section{Değerlendirme ve Sonuç}

2. Dünya Savaşı'nın sona ermesi sonucu, Marshall Planı vasıtasıyla artan Amerikan etkisinin, yönetim bilgisi transferindeki rolünü dönemin kamu iktisadi teşebbüslerinden biri olan Türk Hava Yolları özelinde analiz eden çalışmanın sonuçları, bir çevre ülke olarak Türkiye'deki örgütlere yönelik bilgi transferi sürecinin mekanizmalarını ortaya koyması bağlamında değerlendirilebilir. Söz konusu yönetim danışmanlığı hizmetinin, 1950'li yıllarla birlikte ortaya çıkan; etkili ve verimli iş görme anlayışını öne alan bir Batılılaşma ve/veya Rasyonalizasyon akımının bir yansıması olduğu söylenebilir. Zira çalışmanın kuramsal çerçevesinin çizilmesinde yararlanılan Sahlin-Andersson ve Engwall'ın (2002) modeli bağlamında incelenen yönetim danışmanlığını düşünecek olursak; ABD gibi merkez bir ülkenin teknik yardım fonuyla finanse edildiği ve Büyük Britanya gibi yarı merkez (Üsdiken, 2007; Üsdiken ve Wasti, 2009) bir ülkenin Urwick Orr and Partners adlı danışmanlık firması tarafından; Ford Vakfı'nın finansal desteğiyle kurulmuş "yerel" bir ortak olan Türk Sevk ve Idare Geliştirme Merkezi ile birlikte Türkiye gibi çevrede yer alan (Özen, 2014) bir ülkenin kamu kesimi örgütlerini ıslah etmeye yönelik bir proje olduğu sonucuna ulaşılmıştır. Çalışmanın bulgularını, kuramsal çerçeveye bağıı kalarak değerlendirme adına SahlinAndersson ve Engwall'ın (2002) süreçsel yaklaşımına dönersek, buradaki örnekte yönetim bilgisinin taşıyıcıları Urwick Orr and Partners ile Türk Sevk ve Idare Geliştirme Merkezi iken; finansal kaynak sağlayıcı OECD kanalıyla USAID ve Ford Vakfı; yönetim bilgisinin kaynak sağlayıcısı ise Urwick Orr and Partners'tır.

Danışmanlık faaliyetinin kapsamı ve içeriği bağlamında değerlendirme yapılacak olursa, öncelikle verilen danışmanlık faaliyetinin içeriğindeki 5 konudan yalnızca mali kontrol ve kompüterleşme alanlarında bir ilerleme sağlandığı; buna karşın eğitim ihtiyaçlarının tespiti, iş değerlendirme kapsamındaki liyakat sistemi kurulması ve uzun dönemli planlama gibi alanlarda ise 
herhangi bir ilerleme sağlanamadığı anlaşılmaktadır. Bu noktada, dikkate değer bir husus, ilerleme sağlanan konuların daha ziyade teknik ve finansal nitelikte olduğu; buna karşın örgütsel kültürün dönüşümünü gerektiren ve daha uzun erimli bir çalışma gerektiren ve örgütün sosyal ve kültürel yönüne ilişkin konularda ise kısa sürede bir ilerleme sağlanamadı̆̆ıdır. Projenin somut ve örgütsel değişiklikler getiren sonuçları ise, getirilen öneriler doğrultusunda 1968 yılında Yolcu Hizmetleri Müdürlüğü, 1969 yılında Muhasebe Müdürlüğü yerine Muhasebe ve Mali işler Müdürlüğü ve 1970 yılında ise Elektronik Bilgi Iş̧lemleri Müdürlüğü kurulmasıdır.

Çalışmanın bulgularının birtakım kısıtlara sahip olmakla birlikte, ilgili yazına önemli katkılar sağlayacağı düşünülmektedir. Öncelikle, daha önce de vurgulandığı üzere, tarihsel olarak Türkiye'ye yönelik yönetim bilgisi transferi yazını kamu veya özel olsun iş örgütlerinin durumunu ele almaktan daha çok akademiye odaklanmıştır. Bu bağlamda, çalışmanın sonuçlarının yazında görgül olarak ilgi duyulmamış bir alana katkı sağlayabileceği söylenebilir. Bunun yanında, yönetim bilgisi transferi sürecinde farklı bağlamlardan ve merkezlerden katılan farklı türdeki aktörlerin ve taşıyıcıların rolünü analiz etmesi bağlamında da katkı potansiyeli taşıdığı zikredilebilir. Çalışma, yaptığı bu katkılara karşın ilerideki çalışmalarda giderilmesi muhtemel birtakım kısıtlara sahiptir. Bu kısıtlardan ilki ve belki de en önemlisi, arşiv kısıtlarıdır. Zira danışmanlık hizmetini veren ve alan işletmeleri olan Urwick Orr and Partners ile Türk Hava Yolları'nın kurumsal arşivlerine tüm çabalara karşın erişilememiştir. Benzer bir biçimde, şu an için ulaşılması mali sebeplerle mümkün olmayan Paris'teki OECD arşivi ile ABD'deki US National Archives'a ulaşılması durumunda çalışmanın kısıtlarının giderilmesi kuvvetle muhtemeldir. 


\section{Eskişehir Osmangazi Üniversitesi IïB Dergisi}

\section{Kaynaklar}

Aksoy, Şinasi (1994), "Türkiye'de Kamu İktisadi Teşebbüsleri: Genel Bir Bakış”, Amme Idaresi Dergisi, C.27, S.2: 3-23.

Alatas, Syed Farid (2003), "Academic Dependency and the Global Division of Labour in the Social Sciences", Current Sociology, C.51, S.6: 599-613.

Ali İhsan Poyraz ile kişisel görüşme.

Bedford, Lee (1966), "Sevk ve İdare Müşavirliği”, Sevk ve Idare Dergisi, C.1, S.1: 15-17.

Boel, Bent (2003), The European Productivity Agency and Transatlantic Relations, 1953-1961, Copenhagen: Museum Tusculanum Press.

Brech, Edward; Thomson, Andrew; Wilson, John F. (2010), Lyndall Urwick, Management Pioneer: A Biography, Oxford: Oxford University Press.

Coşkun, Yasin (2015), "1974 Kıbrıs Barış Harekâtının Türk-İngiliz İlişkilerine Etkileri”, Tarih Okulu Dergisi (TOD), C.8, S.22: 449-462.

Cwiklicki, Marek; Alcouffe, Alain (2012), "The Dissemination of Management Innovations through Consultancy in the Postwar Period", Yayınlanmamış Bildiri. Helsinki: 28. EGOS Colloqium.

Devlet Bakanlığı (1952), Türkiye'de Marşal Planı (Başlangııından 1951 Sonuna Kadar), Ankara: Başbakanlık Devlet Matbaası.

Dik, Esra (2009), “1948: Marshall Planıyla 'Hür Dünya'ya Giriş”, (Ed. Birgül Ayman Güler), Açıklamalı Yönetim Zamandizini 1940-1949, Ankara: Ankara Üniversitesi Siyasal Bilgiler Fakültesi Kamu Yönetimi Araştırma ve Uygulama Merkezi: 947-1060.

Djelic, Marie-Laure (2001), Exporting the American Model: The Post-War Transformation of European Business, Oxford: Oxford University Press.

Djelic, Marie-Laure; Sahlin-Andersson, Kerstin (2006), Transnational Governance: Institutional Dynamics of Regulation, Cambridge: Cambridge University Press.

Ege Cansen ile kişisel görüşme.

Engwall, Lars (2007), "The Anatomy of Management Education”, Scandinavian Journal of Management, C.23, S.1: 4-35.

Engwall, Lars; Kipping, Matthias; Üsdiken, Behlül (2016), Defining Management: Business Schools, Consultants, Media, London: Routledge.

Erçek, Mehmet; Günçavdı, Öner (2016), “Imprints of an Entrepreneur and Evolution of a Business Group, 19482010", Business History, C.58, S.1: 89-110.

Erçek, Mehmet; İşeri Say, Arzu (2008), "Discursive Ambiguity, Professional Networks, and Peripheral Contexts: The Translation of Total Quality Management in Turkey, 1991-2002", International Studies of Management \& Organization, C.38, S.4: 78-99.

Erkmen, Haluk (1966), “Bir Türk Müşavirinin İntibaları”, Sevk ve Idare Dergisi, C.1, S.1: 19-20.

Ergun Zoga ile e-posta görüşmesi.

Frenkel, Michal (2005), "The Politics of Translation: How State-level Political Relations Affect the Cross-national Travel of Management Ideas", Organization, C.12, S.2: 275-301.

Frenkel, Michal (2008), "The Americanization of the Antimanagerialist Alternative in Israel: How Foreign Experts Retheorized and Disarmed Workers' Participation in Management, 1950-1970", International Studies of Management \& Organization, C.38, S.4: 17-37.

Frenkel, Michal; Shenhav, Yehouda (2003), "From Americanization to Colonization: The Diffusion of Productivity Models Revisited”, Organization Studies, C.24, S.9: 1537-1561.

Frenkel, Michal; Shenhav, Yehouda (2012), "Management Consulting in Developing and Emerging Economies: Towards A Postcolonial Perspective", (Ed. Timothy Clark), The Oxford Handbook of Management Consulting, Oxford: Oxford University Press: 509-527.

Gantman, Ernesto; Parker, Martin (2006) "Comprador Management? Organizing Management Knowledge in Argentina (1975-2003)", Critical Perspectives on International Business, C.2, S.1: 25-40.

Gephart, Robert P. (2004), "Qualitative research and the Academy of Management Journal", Academy of Management Journal, C.47, S.4: 454-462. 
Guillén, Mauro (1994), Models of Management: Work, Authority, and Organization in a Comparative Perspective. Chicago: University of Chicago Press.

Hansen, Per (2004), "Writing Business History Without an Archive: Newspapers as Sources for Business History, Possibilities and Limitations", (Ed. Carl-Johan Gadd; Staffan Granér; Sverker Jonsson; Ulf Olsson), Markets and Embeddedness: Essays in Honour of Ulf Olsson, Göteborg Ekonomisk-Historiska Institutionen Göteborg University: 99120.

Kabakçı Yurdakul, Işı (2016), "Nitel Veri Analizinin Temelleri”, (Ed. Işıl Kabakçı Yurdakul), Nitel Veri Analizinde Adım Adım Nvivo Kullanımı, Ankara: Anı Yayıncılık: 1-20.

Kalev, Alexandra; Shenhav, Yehouda; De Vries, David (2008), "The State, the Labor Process, and the Diffusion of Managerial Models", Administrative Science Quarterly, C.53, S.1: 1-28.

Kayra, Cahit (1965), OECD, Türk Konsorsiyumu, Projeler Çalışma Grubu Toplantıları Ile Illgili Dokümanlar, Ankara: Devlet Planlama Teşkilatı.

Kerr, Ron (2008), "Transferring New Public Management to the Periphery: UK International Development Organizations Applying Project Technology to China", International Studies of Management \& Organization, C.38, S.4: 58-77.

Kipping, Mathias; Bjarnar, Ove (1998), The Americanisation of European Business, London: Routledge.

Kipping, Mathias; Üsdiken, Behlül; Puig, Nuria (2004), "Imitation, tension, and hybridization: Multiple "Americanizations" of management education in Mediterranean Europe", Journal of Management Inquiry, C.13, S.2: 98-108.

Kipping, Mathias; Engwall, Lars; Üsdiken, Behlül (2008), “Preface: The Transfer of Management Knowledge to Peripheral Countries", International Studies of Management \& Organization, C.38, S.4: 3-16.

Kurt, Mustafa; Özcan, Kerim; Özkal, Enver Samet (2010), “Yönetim Alanında Kayıp Bir Aktör: Türk Sevk ve İdare Derneği", 18. Ulusal Yönetim ve Organizasyon Kongresi, Adana: Çukurova Üniversitesi.

Maliye Bakanlığı (1961a), Individual Reports of State Economic Enterprises in Turkey, Ankara: Yeni Desen Matbaası.

Maliye Bakanlığı (1961b), Kamu Iktisadi Teşebbüslerine Ait Özel Raporlar, Ankara: Maliye Bakanlığı.

Matthews, Martin D.; Boyns, Trevor (2001), A Schedule of the Lyndall Fownes Urwick Archive, Henley: The Management College.

Milliyet, “Sevk ve İdare Müşavirliği İçin Eleman Alınacaktır”, 11 Haziran 1966.

Mir, Raza; Banerjee, Subhabrata Bobby; Mir, Ali (2009), "(How) Does Knowledge Fow? A Critical Analysis of Intra-organizational Knowledge Transfer", (Ed. Subhabrata Bobby Banerjee; Vanessa C. M. Chio; Raza Mir), Organizations, Markets and Imperial Formations: Towards an Anthropology of Globalization, Cheltenham: Edward Elgar: 98-110.

Nergiz, Abdullah (2008), Türkiye'de Sivil Havacılığın Gelişimi ve THY, Yayınlanmamış Yüksek Lisans Tezi. İstanbul: Marmara Üniversitesi.

Özen Aytemur, Janset (2010), Türkiye'de Yönetim Düşüncesinin Erken Dönemleri: Sümerbank, 1930-1945. İstanbul: Libra Yayıncilık.

Özen, Şükrü (2014), "Rhetorical Variations in the Crossnational Diffusion of Management Practices: A Comparison of Turkey and the US", (Ed. Gili Drori; Markus Höllerer; Peter Walgenbach), Global Themes and Local Variations in Organization and Management, London: Routledge: 119-132.

Özen, Şükrü; Berkman, Ümit (2007), “Cross-national Reconstruction of Managerial Practices: TQM in Turkey”, Organization Studies, C.28, S.6: 825-851.

Özsoy, Fahir (1966) Sevk ve İdare Geliştirme Merkezi, Sevk ve Idare Dergisi, C.1, S.1: 11-15.

Pozzi, Daniele (2012), “The Odd Couple: Booz Allen at ENI (1956-1965)”, Management \& Organizational History, C.7, S.4: 303-318.

Reay, T.; Zafar, A.; Monteiro, P.; Glaser, V. (2019), "Presenting Findings from Qualitative Research: One Size Does Not Fit All!.", (Ed. Tammar B. Zilber; John M. Amis; Johanna Mair), The Production of Managerial Knowledge and Organizational Theory: New Approaches to Writing, Producing, and Consuming Theory, Emerald Publishing: 201-216.

Robson, William A. (1965), Report on the State Investment Bank and Its Relations with State Economic Enterprises, the State Planning Organisation, and the Ministries concerned with investment programmes of the State Economic Enterprises, Technical Assistance Programme Turkey - Project No. 56. Paris: OECD.

Sahlin-Andersson, Kerstin; Engwall, Lars (2002), “Carriers, Flows, and Sources of Management Knowledge”, (Ed. Kerstin Sahlin-Andersson; Lars Engwall), The Expansion of Management Knowledge: Carriers, Flows, and Sources, Stanford, CA: Stanford Business Books: 3-32. 


\section{Eskişehir Osmangazi Üniversitesi IïBF Dergisi}

Saint-Martin, Denis (2012), "Governments and Management Consultants: Supply, Demand, and Effectiveness", (Ed. Timothy Clark; Mathias Kipping), The Oxford Handbook of Management Consulting, Oxford: Oxford University Press: 447-464.

Sevk ve İdare Dergisi (1968), Sevk ve İdare Faaliyetleri. Sevk ve Idare Dergisi, C.2, S.11: 43.

Smith, Holroyd (1961), Report on T.H.Y.: Turkish State Airline: Made in the Framework of the Overall Study on the Operations of the State Economic Enterprises in Turkey, Paris: OECD.

Smith, B.; Weed, M. (2007). The potential of narrative research in sports tourism. Journal of Sport \& Tourism, C. 12 , S. 3-4: 249-269.

Srinivas, Nidhi (2008), “Mimicry and Revival: The Transfer and Transformation of Management Knowledge to India, 1959-1990", International Studies of Management \& Organization, C.38, S.4: 38-57.

Topal, Mehmet; Erdemir, Erken; Kırlı, Engin (2012), "Tanzimat Dönemi Sanayileşme Hareketinin Türkiye'de İşletmecilik Anlayışının Oluşumuna Etkileri Hereke Fabrikası ve Nizamnamesi", Süleyman Demirel Üniversitesi Fen-Edebiyat Fakültesi Sosyal Bilimler Dergisi, S.25:37-64.

Türk Hava Yolları 1966 Yıllık Rapor (1967). İstanbul: Türk Hava Yolları A.O.

Türk Hava Yolları 1968 Yıllık Rapor (1969). İstanbul: Türk Hava Yolları A.O.

Türk Hava Yolları 1970 Yıllık Rapor (1971). İstanbul: Türk Hava Yolları A.O.

Türk Hava Yolları 1973 Yıllık Rapor (1974). İstanbul: Türk Hava Yolları A.O.

Türk Hava Yolları 1974 Yıllık Rapor (1975). İstanbul: Türk Hava Yolları A.O.

Türk Hava Yolları (2008). 75. Yılında Türk Hava Yolları, İstanbul: Türk Hava Yolları.

Urwick Orr and Partners International (1968), OECD-Turkish State Economic Enterprises Concluding Report, Paris: OECD. Urwick, Lyndall (1965), Sevk ve Idare Etme Bir Ilim mi? Yoksa Bir Sanat Mıdır?, İstanbul: Türk Sevk ve İdare Derneği.

Üsdiken, Behlül (1996), "Importing Theories of Management and Organization: The Case of Turkish Academia”, International Studies of Management \& Organization, C.26, S.3: 33-46.

Üsdiken, Behlül (2004), “Exporting Managerial Knowledge to the Outpost: Penetration of 'Human Relations' into Turkish Academia, 1950-1965", Management Learning, C.35, S.3: 255-270.

Üsdiken, Behlül (2007), “Commentary: Management Education Between Logics and Locations”, Scandinavian Journal of Management, C.23, S.1: 84-94.

Üsdiken, Behlül (2014), “Centres and Peripheries: Research Styles and Publication Patterns in 'Top'us Journals and Their European Alternatives, 1960-2010", Journal of Management Studies, C.51, S.5: 764-789.

Üsdiken, Behlül (2015), “Açılıs Konuşması”, Yönetim Alanında Kayıp Bir Aktör: Türk Sevk ve Idare Derneği Temalı III. İşletmecilik Tarihi Çalıştayı, İstanbul: Marmara Üniversitesi.

Üsdiken, Behlül; Selekler, Nisan (1996), "Türkiye'de İşletme Alanında Eğitim ve Araştırmanın İlk Dönemleri”, IV. Ulusal Yönetim ve Organizasyon Kongresi, Ankara: Başkent Üniversitesi.

Üsdiken, Behlül; Çetin, Demet (2001), “From Betriebswirtschaftslehre to Human Relations: Turkish Management Literature Before and After the Second World War", Business History, C.43, S.2: 99-124.

Üsdiken, B. ve Wasti, S. A. (2009). Preaching, teaching and researching at the periphery: Academic management literature in Turkey, 1970-1999. Organization Studies, 30(10), 1063-1082.

Üsdiken, Behlül; Selekler, Nisan; Çetin, Demet (1998), "Türkiye’de Yönetim Yazınına Egemen Anlayışın Oluşumu: Sevk ve İdare Dergisi Üzerine Bir İnceleme”, Amme Idaresi Dergisi, C.31, S.1: 57-87.

Wailes, Nick; Michelson, Grant (2008), "The Transfer of Management Ideas to a Western "Periphery": The Case of Corporate Social Responsibility in Australia", International Studies of Management \& Organization, C.38, S.4: 100118.

Wang, Yin (2009), Global Management Consultancy in China, Yayınlanmamış Yüksek Lisan Tezi, School of Organization and Management, New South Wales: University of New South Wales. 
The aim of this study is to examine the consulting services of Urwick Orr and Partners to Turkish Airlines from 1967 to 1971. It is also aimed to explore the relationship between Urwick Orr and Partners as an international consulting firm and Türk Sevk ve İdare Derneği as a local partner. Last but not least, it is aimed to describe the historical development of management consultancy in Turkey as a peripheral country and to contribute business and management history literature of Turkey.

The theoretical framework of the study is the diffusion of management knowledge and practices across contexts and countries. After the World War II, direct U.S. influence was the strongest for the transfer of management models. In this regard, for the diffusion of management knowledge, the United States is the one and only center. Moreover, during most of the twentieth century, the United States was the main producer and even more importantly the main diffuser of management knowledge and practices worldwide. Empirical studies showed that the vast majority of the carriers of management knowledge originated in the United States, including the major foundations (e.g. Ford Foundation, Rockefeller Foundation), management consultancy firms (e.g. Booz Allen Hamilton, Urwick Orr Partners) and some business schools (Harvard Business School). Those abovementioned studies highlighted the role and activities of the carriers in the transfer of management knowledge. Sahlin-Andersson and Engwall (2002) used the carrier concept when analyzing those who are professing, providing, and circulating management ideas and models. With the expansion of carriers such as consultants, business schools and the media the supply of management ideas has expanded. According to Sahlin-Andersson and Engwall (2002), carriers 'circulate management knowledge' and these carriers are categorized into four types of organizations: multi-divisional companies, business schools, management consultancies, and media companies. Engwall, Kipping and Üsdiken (2016) also stated that like business schools and business media the management consultancy is one of the most important carriers of management knowledge from center to periphery. In the context of post-World War II reconstruction, some organizations at the intergovernmental level, such as the Organization for European Economic Cooperation (OEEC) and the European Productivity Agency have played a very important role at the transfer of management knowledge and models (Boel 2003).

Compared to the existing literature for the more industrialized and developed countries, empirical research on the transfer of management knowledge from center to periphery is very weak. For filling this gap in the literature, a historical narrative approach is constructed to allow for in-depth analysis of consulting services of Urwick Orr and Partners to Turkish Airlines from 1967 to 1971 . To reach the aim of the study, a triangulated data-collection approach adopted. The data are gathered from multiple sources that include semi-structured interviews, archival materials, various kinds of text and commentary and archival articles of newspapers. Narrative analysis refers to a cluster of analytic methods for interpreting texts or visual data that have a storied form. For this reason, narrative analysis is used in this study to explore the context, content and scope of consulting services and to construct a meaningful narrative.

The temporal phases approach is adopted in the presentation of the research results. According to Reay et.al. (2019), temporal phases approach is closely associated with longitudinal research and one of the main advantages of the temporal approach is that it maintains the integrity of findings and produces a readable narrative.

Research results show that, this consulting service considered as a part of an extensive rationalization project of State Economic Enterprises in Turkey. In this regard, it is found that this consulting service is related with U.S. technical assistance to Turkey after World War II. U.S. Agency for International Development (AID) and Organisation for European Economic Co-operation (OEEC) the predecessor of the OECD are main carriers of the knowledge transfer. Those organizations made special surveys on the State Economic Enterprises in Turkey and prepared two series of reports on the rationalization and reorganization of Turkish State Economic Enterprises. According to those reports, it was should be reorganized managerial and rationalize the activities of Turkish Airlines. For this purpose, State Planning Organization (DPT) hired Urwick Orr and Partners as a consultancy firm to reorganize Turkish Airlines. This rationalization and reorganization project was funded by OECD. Urwick Orr and Partners was main organization and Turkish Management Development Center which established by funds from Ford Foundation and OECD was the local partner in this project. The project suddenly ended in 1971, because of both political instability of Turkey and its reflections on Turkish Airlines. It is concluded that Urwick Orr and Partners and Turkish Management Development Center were the main carriers of this knowledge transfer project. As Kipping, Engwall and Üsdiken (2008) emphasized, the state and various kinds of its associations have played important role in this transfer process. 
Eskişehir Osmangazi Üniversitesi IißBF Dergisi 